Mitteilungen der Österreichischen Geographischen Gesellschaft, 158. Jg. (Jahresband), Wien 2016, S. 289-308

\title{
FACHDIDAKTIK
}

GEOGRAPHICAL DIDACTICS

\section{A Comparison of Content Standards Documents for Geographical Tuition in China and the United States}

Fengtao GuO, Shanghai, Joseph P. Stoltman, Kalamazoo (Michigan, USA), Yushan DuAn, Shanghai, and Terri Bourke, Brisbane (Australia)*

with 6 figures and 6 tables in the text

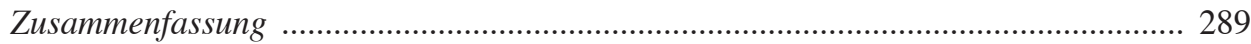

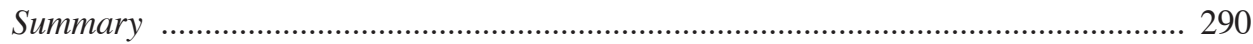

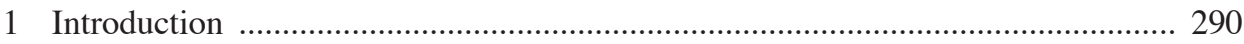

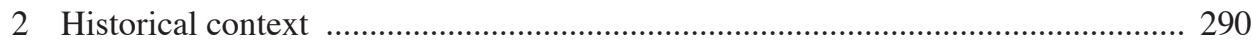

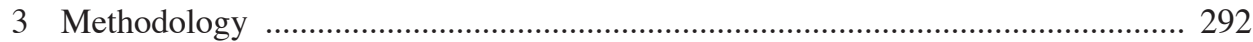

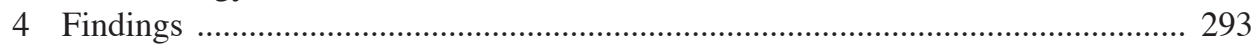

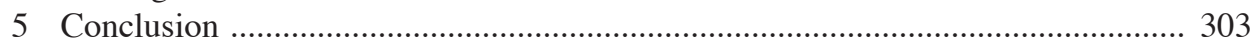

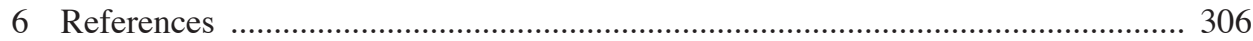

\section{Zusammenfassung}

Ein Vergleich von Dokumenten über inhaltliche Standards für den Geographieunterricht in China und den Vereinigten Staaten

Die Vereinigten Staaten und China veröffentlichen nationale Geographie-Standards, die festlegen, welches Wissen, welche Begriffe, Grundsätze und Fähigkeiten Schüler kennen bzw. haben sollten. Der Beitrag vergleicht die Geographie-Standards dieser beiden

\footnotetext{
* Fengtao Guo, PhD., School of Geographic Sciences, East China Normal University, 500 Dongchuan Road, Minhang District, Shanghai 20024, China; email: fengtao.guo@foxmail.com; Joseph P. Stoltman, Prof.PhD., Department of Geography, Western Michigan University, 1903 W Michigan Ave, Kalamazoo MI 490085433 USA; email: joseph.stoltman@wmich.edu; http://www.wmich.edu/geography/directory/stoltman; Yushan Duan, Prof. PhD., School of Geographic Sciences, East China Normal University, 500 Dongchuan Road, Minhang District, Shanghai 200241, China; email: ysduan@126.com; Terri BouRkE, PhD., Faculty of Education, Queensland University of Technology, Victoria Park Road Kelvin Grove QLD 4059, Australia; email: theresa.bourke@qut.edu.au
} 
Länder, insbesondere die Standards für die Mittelschule, wobei er Inhaltsanalyse und Begriffskartierung als Methoden anwendet. Die Ergebnisse zeigen, dass trotz etlicher Ähnlichkeiten zwischen den Dokumenten der beiden Länder doch auch markante Unterschiede bestehen, auf die besonders hingewiesen wird.

Schlagwörter: Geographie-Standards, Vergleich, Vereinigte Staaten, China, Begriffskartierung

\section{Summary}

The United States and China have national geography standards that identify the knowledge, concepts, principles, and skills that students should know and be able to use. This paper compares the geography standards of these two countries, specifically the standards for the middle school using content analysis and concept mapping as the methodological technique. The findings suggest that although there are a number of similarities between both country's documents, there are also significant differences, which are worth pointing out.

Keywords: geography standards, comparison, United States (U.S.), China, concept mapping

\section{Introduction}

Education standards have been set out and implemented in many parts of the world. The purpose of this paper is to compare two standards documents from two different parts of the world, specifically the United States of America (USA) and China. The opening section outlines the historical context of where the notion of standards came from and how they entered the field of education. The research questions for this study are then posed followed by the methodology section, which details the use of document content analysis and concept mapping as an innovative analytic tool in order to compare both documents. Then the findings are outlined revealing that there are a number of similarities and significant differences, which are worth point out between both country's standards. We expect this research can contribute to explore aspects of core/essential knowledge, powerful knowledge, the rationale applied for selection of curriculum content or emergent capabilities approaches to conceptualising the curriculum (e.g. LAMBERT 2011), as appropriate to their national contexts.

\section{Historical context}

As early as 1862 in the United Kingdom, the 'Revised Code' introduced standards to the field of education (ALDRICH 2000). In the United States in the early $20^{\text {th }}$ century, the so- 
called 'social efficiency movement' attempted to apply methods and concepts in industrial production to the organisation of teaching and learning processes (WALDOw 2015). John Franklin Воввітт, a leading proponent of the movement believed that by specifying the desired product, that is students' knowledge and skills, there was a greater guarantee of successful and efficient production. The content of the standards was determined by consistently looking at the requirements and wishes of customers (i.e., society), not looking at what the 'ultimate workers' (i.e., the pupils) wanted.

In the middle of the $20^{\text {th }}$ century, Ralph W. TYLER, who was an influential American educator in the field of curriculum-making and evaluation authored the classic book "Basic Principles of Curriculum and Instruction" (TYLER 1950). In this book, TYLER translated some of the key principles from this earlier movement into a form acceptable to educators, which had more emphasis on pedagogy. TYLER also took into consideration curricular objectives including how students learned and disciplinary knowledge of traditional school subject matter (KLIEBARD 1995).

In the last two decades of the $20^{\text {th }}$ century, test scores have commonly been used to make claims about the success or failure of schools. Many believe that school failure could result in a country's loss of dominance in the global market place (GABBARD 2003). "A Nation at Risk" (ANAR), a report by the U.S. National Commission on Excellence (NCEE 1983) called for increased achievement in American schools. "Accountability" became the new catchword in the realm of public services, and elsewhere, as "efficiency" was to the social efficiency movement (Hopmann 2007; Rhoten, CARnoy, Chabra'N \& Elmore 2003, p. 15). Recommendation B from the ANAR stated that the nation should introduce "rigorous and measurable standards" as part of a general effort to raise achievement, including state-wide standardised tests of achievement (NCEE 1983, p. 125). Following the ANAR was a wave of reform activity, for example, "Geography for Life: National Geography Standards" developed by the Geography Education National Implementation Project (GENIP) on behalf of the Association of American Geographers, American Geographical Society, National Council for Geographic Education, and the National Geographic Society. These standards, in a core subject demonstrated for the first time to a larger national audience that educational standards were feasible (RAVITCH 1995). The No Child Left Behind Act (NCLB) transformed standards-based reform into policy so that students should know (content standards), and do (performance standards). Ideally, the knowledge, skills and dispositions described in the standards mirrored those demanded in the world outside school (AMERICAN FEDERATIOn OF TEACHERs 2009).

Now, standards-based reform is widespread with the development of geography standards, not only in the United States but also in other countries such as China, Germany, and Australia. Such geography standards were established as a framework to provide guidelines about geography teaching and what students of geography should know. For the purpose of this paper, the standards from the United States are compared with China, as examples of standards representing western and eastern cultures, very different policy landscapes.

According to BUTT \& LAMBERT (2014), geographical knowledge is a vital component of the education of young people across the globe, so the research undertaken here reveals how such a vital component of education is expressed in the standards documents of two 
different countries. Specifically, a comparison is made between the content standards at the middle school grades in two of the world's largest educational systems: China and the United States. In the United States of America, geography is studied in social studies, which rarely receives federal funding, and geography as a subject is in a diminished state with all but a minority of schools offering it (BUTT \& LAMBERT 2004). In China, the basic education curriculum has experienced eight waves of changes since the founding of the new China in 1949.

In China, the school system is mainly "six-three-three", six years elementary and three years middle school is compulsory education. There are two geography standards in middle school and high school. Chinese geography teachers are largely specialist-trained in high schools, however, other teachers who do not major in geography may teach geography in some rural areas. Geography teaching is high-stakes especially in high school where geography is part of the college entrance examination. As an obligatory course in middle schools, geography can be studied as a stand-alone subject or as part of an integrated approach. Where school study of geography is subject-specific, there are usually two classes every week for around 90 minutes.

There is little knowledge of the standards for China in the United States, but the U.S. Geography Standards $1^{\text {st }}$ edition have been available in China since 1997 translated by Xunfeng Li and Chaoen HuANG. In order to establish the similarities and differences between the content standards in geography for China and the U.S., two research questions were formulated:

1. What are the content structures for the geography standards in the United States and China?

2. What are the similarities and differences of the geography content standards between the United States and China?

\section{Methodology}

The methodology used for this study is a combination of document analysis and concept mapping. The document analysis procedure is outlined first before the concept mapping technique is detailed.

Document analysis as a qualitative research approach enables the researcher to discover insights relevant to the research problem (MERRIAm 1988) and provides a systematic procedure for evaluating documents in terms of their motivation, intent and purpose (Australian National University - Academic Skills and Learning Centre, ANU-ASLC, 2009). The two documents under investigation were "Geography for Life: National Geography Standard, Second Edition" (Gallagher-HefFron \& Downs 2012) and "Geography Curriculum Standards for Compulsory Education” (Ministry of Education of the PeOPle's Republic of China 2011).

The initial comparison took into consideration the type and structure of the documents, when they were written, the voices of authority behind the documents, as well as the purpose of the documents and why they were written (ANU-ASLC 2009). Each document 
was skimmed (superficial examination), before a full reading (thorough examination) took place so that the content of the document could be interpreted (BOwEN 2009) so that comparisons could be made. The more thorough examination of the documents took place using concept mapping techniques.

As a research tool, concept mapping grew out of work by NovAK (1972) and his graduate students at Cornell University (Rowell 1978). It has been employed in diagnosis and testing, instructional and curriculum development, and more recently as a metacognitive aid in helping students "learn how to learn" (NovaK 1990). Concept mapping is unique in its philosophical basis, which "makes concepts, and propositions composed of concepts, the central elements in the structure of knowledge and construction of meaning." (NovAK \& GowIN 1996, p. 7). By using this technique here, the researchers were able to extract the main and subordinate concepts that supported a standard, so that the content could be organised, which made comparison clearer and easier.

\section{Findings}

\subsection{Structure/purpose of the documents}

The U.S. and Chinese standards documents are published in booklet form, although the latter are also available online. The Chinese standards consist of 31 pages and are divided into four main parts, which are named Introduction; Course objectives; Content standards; and Implement standards. The U.S. document is much larger consisting of 117 pages but also has four parts: Introduction; Doing geography; Knowing about the world; and Asking and answering questions about the world. More details of the different parts can be seen in Table 1.

The "Geography for Life Standards" from the U.S. was first published in 1994 by GENIP. These standards were revised and a second edition was released in 2012. The voices of authority who compiled this document were Professors Roger Downs and Joseph Stoltman, and Drs. Sarah Bednarz and Susan Gallagher-Hefrron, all influential American geographers/geography educators. The revision was a response to the "Goals 2000: Educate America Act", to ensure that the national geography standards continue to capture the most important and enduring ideas in geography and that the standards remain challenging to students, specifically in areas like problem-solving geospatial technologies such as geographic information systems (GIS), global positioning systems (GPS), and remote sensing (RS). These areas provide a variety of career opportunities for the future.

The U.S. content standards are designed to focus on three grade level clusters: Primary, middle, and high school. Each grade level cluster includes a set of specific grades. For example, the geography content standards intended for primary grades are presented at $4^{\text {th }}$ grade, which includes grades $\mathrm{K}, 1,2,3$ and 4 . The cluster implies that each of the grades, $\mathrm{K}-4$ up to that time in the school process, will have contributed to the development of content and skills. The middle school cluster includes grades 5, 6, 7, and 8. For high school the cluster includes grades $9,10,11$, and 12 . These content standards suggest a grade level 


\begin{tabular}{|c|c|}
\hline United States & China \\
\hline $\begin{array}{l}\text { Part I: } \\
\text { a. Introduction: The geographically informed person; } \\
\text { b. What's new in the Second Edition and why }\end{array}$ & \multirow{2}{*}{$\begin{array}{l}\text { Part I: Introduction } \\
\text { a. Nature of course } \\
\text { b. Rationale for course } \\
\text { c. Design for course }\end{array}$} \\
\hline $\begin{array}{l}\text { Part II: } \\
\text { a. Doing geography: The geographic lens on the world; } \\
\text { b. Looking at the world in multiple ways: geographic } \\
\text { perspectives }\end{array}$ & \\
\hline \multirow{2}{*}{$\begin{array}{l}\text { Part III: } \\
\text { Knowing about the world: Geographic content knowledge } \\
\text { a. Essential element 1: The world in spatial } \\
\text { b. Essential element 2: Place and regions } \\
\text { c. Essential element 3: Physical systems } \\
\text { d. Essential element 4: Human systems } \\
\text { e. Essential element 5: Environment and society } \\
\text { f. Essential element 6: The uses of geography }\end{array}$} & $\begin{array}{l}\text { Part II: Course objectives } \\
\text { a. Knowledge and skills } \\
\text { b. Process and methods } \\
\text { c. Emotion, attitude and value }\end{array}$ \\
\hline & $\begin{array}{l}\text { Part III: Content standard } \\
\text { a. Earth and globe } \\
\text { b. World geography } \\
\text { c. Geography of China } \\
\text { d. Local geography }\end{array}$ \\
\hline $\begin{array}{l}\text { Part IV: } \\
\text { Asking and answering questions about the world: } \\
\text { Geographic skills; }\end{array}$ & $\begin{array}{l}\text { Part IV: Implement standards } \\
\text { a. Teaching suggestions } \\
\text { b. Assessment suggestions } \\
\text { c. Writing textbook suggestions }\end{array}$ \\
\hline
\end{tabular}

Tab. 1: A comparison of the structure of the national geography standards in China and the United States

progression of content based on the curriculum most widely used in the U.S. It is referred to as the expanding environment in grades K-8. The high school curriculum has content courses in geography, history, civics and economics.

In China, the issue of the "Decision on the Deepening of Educational Reform and the Full Promotion of Quality-Oriented Education" in 1999 symbolised the start of the eighth wave of curriculum reform in China (CUI \& ZHU 2014). Different from the previous reform, which was limited to textbooks, the basic concept of the new wave was seen as both revitalisation of the Chinese people and development of each student (CUI \& ZHU 2014). According to CHEN \& LIN (2012), geography had a new challenge posed by these new reforms, particularly in the areas of population, resources and the environment. Two geography standards were established in China, one for middle school, the other for high school. Between 2003 and 2010, the Ministry of Education conducted two largescale surveys of geography syllabus and revised them three times. For example, in 2003, the survey investigated 110,000 teachers covering 42 nation-level experimental zones of curricula innovation and 29 provinces, municipalities and autonomous regions (CHEN \& LiN 2012). Educators and geographers were also consulted and this resulted in the new geography standards published in 2011. The members of the standards content committee included Professors Chen ChEng, Peiying Lin, Yushan DuAn and Min W ANG, geographers/ 
secondary school geography teachers. However, the geography standards for high school have been revised.

The geography content standards for China are organised somewhat differently from the U.S. They are divided into four parts and it is assumed that every grade level in middle school where geography is taught will address the content at that appropriate level. The study of geography in China begins in the primary school. However, a specific content focus on geography begins in the middle school when students have their first specialised course in the discipline. The content standards for China follow a grade-to-grade progression with 100 specific geographic content standards addressed in the Chinese middle school specifically (Ministry of Education of the People's Republic of China 2011).

\subsection{Organising the comparative research}

The task of comparing and contrasting the geography standards for the two countries revealed complexity. On the one hand, the format, or appearance, and design of the standards documents were different for each country. On the other hand, the grade band, or cluster of grades used in the organisation and focus were approximate when age and grade were compared. In order to compare the content prescribed in each document, Part III was specifically investigated. As can be seen in Table 1, the geography content standards for China and the United States have somewhat different basic organisational frameworks. China has four major topics of study whereas the content of the American version has six essential elements (Gallagher-HefFron \& Downs 2012).

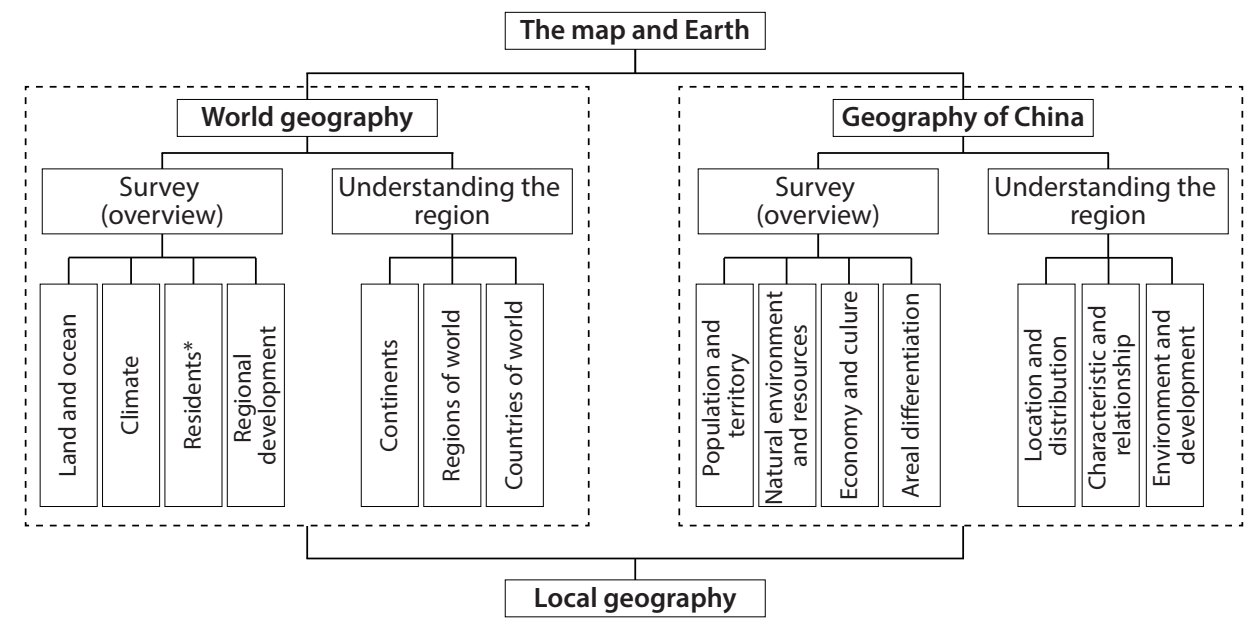

Fig. 1: The framework for middle school geography in China. The framework presents the key topics. Terminology has been generalised from Mandarin in several parts. For example, residence* as a topic in the standards for China includes race, population, region, language, and settlement. 


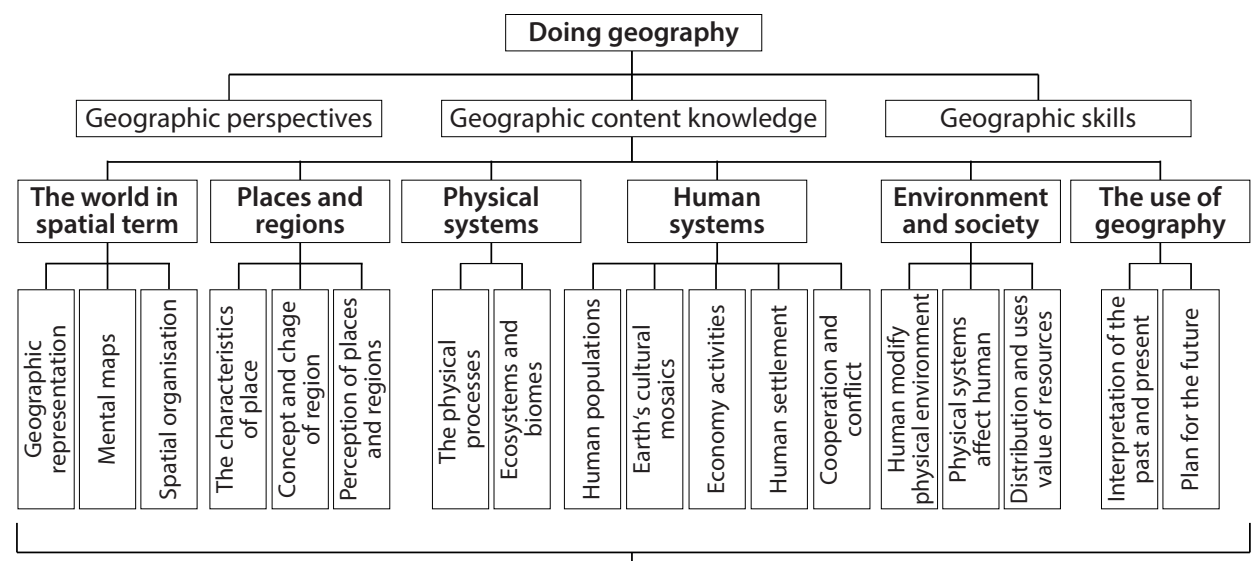

Geographically informed person

Fig. 2: The framework for middle school geography in the U.S.

In China, each standard for middle school presents content a student is expected to do, several activity suggestion examples for one topic. In the U.S., each standard presents knowledge statements and performance statements with several examples (three examples for one performance) of what a student should be able to demonstrate using the content. The structure of the standards for both countries is sequential in their step-by-step approach to implementation making the accessibility and functionality of both documents easy for geography teachers, curriculum specialists, and assessment developers.

The general frameworks for the geography standards from each country were organised into comparable graphics, shown for China in Figure 1 and the United States in Figure 2. The examination of the frameworks further demonstrated common topics and distinct differences in the standards.

\subsection{Similarities of the standards}

There are four main similarities between the investigated documents, which are now outlined.

The first similarity is that both standards documents include themes as organisers for the content standards. In the standards for China, for example, the first order theme "World Geography" has five subordinate themes including Regional Development, which becomes a second order theme. The second order theme, Regional Development, likewise has several further divisions of content. The design of the standards for China represents a hierarchy of concepts that may be embellished by the teacher or the curriculum documents that emerge from the standards. In the United States, there is a similar hierarchy of conceptual terminology to guide the user of the standards. 
The second similarity is the use of verbs to capture what a student should be able to demonstrate as a behaviour or performance upon completion of geography instruction. The United States standards rely on single word verbs to denote actions and behaviours, while in China the verbs are somewhat comparable, but often include a more elaborated pedagogical foundation and examples of actions and behaviours that may be expected. These are shown in Table 2. The Chinese standards present a specific example of behaviour or demonstrated ability by the students in the behavioural verbs column.

\begin{tabular}{|c|c|c|c|c|c|c|}
\hline \multirow{2}{*}{\multicolumn{2}{|c|}{$\begin{array}{c}\text { Objective } \\
\text { classification: } \\
\text { China }\end{array}$}} & \multicolumn{3}{|c|}{ Learning level: China } & \multirow{2}{*}{$\begin{array}{l}\text { Behavioural } \\
\text { verbs: } \\
\text { China }\end{array}$} & \multirow[b]{2}{*}{ USA } \\
\hline & & $\begin{array}{c}\text { Declarative } \\
\text { level }\end{array}$ & $\begin{array}{c}\text { Procedural } \\
\text { level }\end{array}$ & $\begin{array}{c}\text { Transfer } \\
\text { level }\end{array}$ & & \\
\hline \multirow{6}{*}{$\begin{array}{l}\text { Outcome } \\
\text { goals }\end{array}$} & \multirow{3}{*}{$\begin{array}{l}\text { Know- } \\
\text { ledge }\end{array}$} & Know & & & $\begin{array}{l}\text { Speak; Describe; } \\
\text { Memorise; } \\
\text { Read; Identify; } \\
\text { Find; Point out; } \\
\text { List example }\end{array}$ & \multirow{9}{*}{$\begin{array}{l}\text { Identify; } \\
\text { Describe; } \\
\text { Construct; } \\
\text { Analyse; } \\
\text { Explain; } \\
\text { Compare; } \\
\text { Evaluate; }\end{array}$} \\
\hline & & & Understand & & $\begin{array}{l}\text { Distinguish; } \\
\text { Sum up; Explain } \\
\text { Compare; } \\
\text { Illustrate }\end{array}$ & \\
\hline & & & & Application & $\begin{array}{l}\text { Design; Write; } \\
\text { Brief Evaluate }\end{array}$ & \\
\hline & \multirow{3}{*}{ Skill } & Imitation & & & $\begin{array}{l}\text { Simulate; } \\
\text { Demonstrate }\end{array}$ & \\
\hline & & & $\begin{array}{l}\text { Independent } \\
\text { operation }\end{array}$ & & $\begin{array}{l}\text { Make; Draw; } \\
\text { Measure }\end{array}$ & \\
\hline & & & & Transfer & Connect with & \\
\hline \multirow{3}{*}{$\begin{array}{l}\text { Experience } \\
\text { goals }\end{array}$} & \multirow{2}{*}{$\begin{array}{l}\text { Process } \\
\text { and } \\
\text { method; } \\
\text { Emotion, } \\
\text { attitude } \\
\text { and value }\end{array}$} & $\begin{array}{l}\text { Experience } \\
\text { (feel) }\end{array}$ & & & Visit; Observe & \\
\hline & & & $\begin{array}{l}\text { Reflect } \\
\text { (identity) }\end{array}$ & & Concern & \\
\hline & & & & $\begin{array}{l}\text { Compre- } \\
\text { hend (inter- } \\
\text { nalise) }\end{array}$ & $\begin{array}{l}\text { Cultivate; } \\
\text { Set up }\end{array}$ & \\
\hline
\end{tabular}

Source: ZHong 2001; SHI \& CUI 1999

Tab. 2: A comparison of the actions expected of students who are studying standardsbased geography in China and the United States

The third similarity is that both documents pay particular attention to human systems of geography. Five of the 18 standards in the United States are categorised within human 
systems, and in China there are four major human geography concepts that are equivalent to human systems. These are shown in Table 3. Nearly all the topics in the standard for the United States could be found in the standard of China, such as population, cultural mosaics, economic interdependence, human settlement. But contents about the division and control of the Earth's surface was rare in the standard of China.

The final similarity is that throughout the standards documents from both countries there is a concerted focus on relating the totality of the document through applying geography content and skills. That relationship is established in the U.S. document through the central focus on the spatial and ecological perspective. The major goal of the standards in the U.S. is to positively impact (1) geographic perspective, (2) knowledge acquisition, and (3) skills (Gallagher-HefFron \& Downs 2012). In China, the central goal is represented by a three-dimensional focus on (1) objective-knowledge; (2) skill, process and method; and (3) emotion, attitude and value. The content standards for both countries emphasise the dynamism of geography as a school subject.

\subsection{Differences in the standards}

Whilst there are four similarities between the documents, there are also five major differences, which are now outlined.

The first difference is that there is less emphasis within the U.S. standards on physical systems. Two of the 18 standards in the U.S., or $11 \%$, are focused on physical geography, which is offset by the greater attention to human geography in the social studies curriculum of U.S. schools. In China, approximately $17 \%$ of the standards and three topics are devoted to physical systems (Table 3).

\begin{tabular}{|l|l|}
\hline \multicolumn{1}{|c|}{ United States } & \multicolumn{1}{c|}{ China } \\
\hline The world in spatial terms & The map; \\
\hline Place and regions & $\begin{array}{l}\text { Areal differentiation; Regional knowledge of the world and } \\
\text { China }\end{array}$ \\
\hline Physical systems & Earth and globe; Land and ocean; Climate \\
\hline Human systems & $\begin{array}{l}\text { Resident; Regional development; Population and territory; } \\
\text { Economy and culture; }\end{array}$ \\
\hline Environment and society & Physical environment and resource; Region knowledge \\
\hline The use of geography & Local geography applications \\
\hline
\end{tabular}

Tab. 3: Comparison of the geography standards for the United States and China was classified by essential elements for the U.S. standards and subordinate topics for China

The second difference is that the geography standards in each country are addressed in a different manner. In the United States the geographic skills are represented by an inquiry process that has five specific steps guided by questions (Table 4). The U.S. standards do 
not delve into traditional skill sets such as map and graph reading. The interpretation of maps and graphs are subsumed, without specific mention, within the organising and analysing steps of the inquiry process. In China, the skills have somewhat greater specificity, although subordinate skills, such as map interpretation are not mentioned (Table 4). The geography standards in China extend skills to the interpretation and application of rules and principles of geography. Two objectives in geography are: (1) Knowledge and skills, and (2) Methods and process (Table 4).

\begin{tabular}{|c|c|}
\hline $\begin{array}{l}\text { Geographic skills: } \\
\text { United States }\end{array}$ & $\begin{array}{c}\text { Geographic skills: } \\
\text { China }\end{array}$ \\
\hline $\begin{array}{l}\text { 1. Asking geogra- } \\
\text { phic information; } \\
\text { 2. Acquiring geogra- } \\
\text { phic information; } \\
\text { 3. Organising geo- } \\
\text { graphic informati- } \\
\text { on; } \\
\begin{array}{l}\text { 4. Analysing geogra- } \\
\text { phic information; }\end{array} \\
\begin{array}{l}\text { 5. Answering geo- } \\
\text { graphic questions }\end{array}\end{array}$ & $\begin{array}{l}\text { 1. Knowledge and skills } \\
\text { A. Grasp the basic knowledge of the map and Earth, explain physical } \\
\text { geography's role in forming the environment and its influence to } \\
\text { human activity, such as landform, climate, and al.; recognise area } \\
\text { differentiation in population, economy and cultural development. } \\
\text { B. Knowing the general geography of world, China and hometown; the } \\
\text { connection between hometown and country, China and world. } \\
\text { C. Knowing the significant issues of humans, resources, environments } \\
\text { and developments; knowing the interrelation between human activity } \\
\text { and environment. } \\
\text { D. Acquiring geographic information and expressing geographic infor- } \\
\text { mation using written narrative, map and graph images; } \\
\text { E. Conducting geographic observation, geographic experiments, and } \\
\text { geographic surveys. } \\
\text { 2. Process and method } \\
\text { A. Accumulate geographic representation by perceiving geographical } \\
\text { objects and phenomena using various methods. Learn to process } \\
\text { geographic information collected, forming geographic concepts, ge- } \\
\text { neralising about geographic features, and applying geographic rules, } \\
\text { use methods of comparing, contrasting, and applying inductive and } \\
\text { deductive reasoning to evaluate information. } \\
\text { B. Analyse and judge geographic observations and information as they } \\
\text { are related to geographic concepts and basic principles. } \\
\text { C. Processes, innovations and practical ability; being skilled in asking } \\
\text { question, collecting information, using related knowledge and me- } \\
\text { thods and resolving problems. } \\
\text { D. Express and communicate experiences, ideas and outcomes in lear- } \\
\text { ning geography using appropriate methods to resolve issues. }\end{array}$ \\
\hline
\end{tabular}

Tab. 4: Comparison of the geographic skills in the U.S. and China geography standards

The third difference between the two standards documents is in the progression sequence. The U.S. document and standards present a scaffolding of the content across the grade bands, elementary, middle and high school. Each of the content standards is revisited several times across these grade bands. Alternatively, in China the content standards follow a linear pattern of presentation, suggesting sets of learning projections. The result is 
that the standards for China represent a narrower view of the content of geography whereas the U.S. content standards represent a wider, more inclusive view.

The fourth difference is that the geography standards in China are responsive to the new curriculum reform beginning in the $21^{\text {st }}$ century. The reform directed geography study in middle schools in anticipation of continued study in high school without repetition of content. One result has been that the title of each chapter in a recent geography textbook (YUAN 2012) has been produced in accordance with the topics and themes of the content standards, and represents the linear design of the standards. This alignment is shown in Table 5.

\begin{tabular}{|l|l|}
\hline \multicolumn{1}{|c|}{ Geography standards (China) } & \multicolumn{1}{|c|}{$\boldsymbol{7}^{\text {th }}$ grade geography textbook chapter (China) } \\
\hline $\begin{array}{l}\text { 1. Earth and globe } \\
\text { a. The Earth's shape, size and movement } \\
\text { b. Globe }\end{array}$ & $\begin{array}{l}\text { Introduction: Discuss geography with students } \\
\text { Chapter 1: Map and Earth }\end{array}$ \\
& $\begin{array}{l}\text { Section 1: Earth and globe } \\
\text { Section 2: The movement of Earth } \\
\text { Section 3: The reading of map } \\
\text { Section 4: Topography interpretation }\end{array}$ \\
\hline 3. Land and ocean & Chapter 2: Ocean and land \\
a. Land-sea distribution & Section 1: Ocean and continent \\
b. Land-sea changes & Section 2: Land-sea changes \\
\hline 4. Climate & Chapter 3: Climate and weather \\
a. Weather & Section 1: Changeable weather \\
b. Temperature and precipitation distribution & Section 2: Temperature change and distribution \\
c. Main types of climate & Section 3: Precipitation change and distribution \\
& Section 4: Climates of the world \\
\hline
\end{tabular}

Source: YUAN 2012

Tab. 5: The first three chapters of "Geography for Grade-7 (First Semester)" published in 2012 by People's Education Press show the close alignment with geography content standards.

The final difference between the two sets of standards rest with region. Regions are areas of the Earth's surface with unifying physical and/or human characteristics in the standards of the United States. "Region" is included in both standards documents, but not treated the same within each. The difference is with the number of standards in each document. Regional geography in the content standards of China includes 35 standards. The U.S. presents three standards representing places and regions. This difference reflects the greater attention to regional geography in the content standards of China. This attention to regional geography is reflected in the textbook publication already mentioned.

In summary, although both documents are organised by themes with verbs used to illustrate geographic behaviours particularly focusing on human geography and relationships, there are significant differences, which include the emphasis on physical geography, how skills are addressed as well as the use of text books and the focus on region as 
a concept. The underpinning concepts are now further explored using concept-mapping techniques.

\subsection{Concept development within the geography content standards}

The comparative study of the content standards of China and the United States was predicated upon the content presented in the standards. Therefore, the clarity and accessibility of the concepts of geography within the standards documents were investigated using concept maps. Two topics were selected for the development of the concept maps: Population and physical systems. Population is one of the basic content of the human system, which can be easier identified in both standards. In addition, the physical system hasn't received much attention in both standards, but it is important for geography. For these reasons, we choose these two topics and also can include main content of geography, human geography and physical geography.

The design of the concept maps followed generally accepted procedures (HoLLEY \& DANSEREAU 1984). The following steps were applied in developing the concept maps.

1. Begin with a basic topic or concept from the standards and examine the structure and content;

2. Identify the main concepts and the sub-concepts for the topic;

3. Arrange the concepts so that the related concepts are in clusters;

4. Connect the concepts with lines so that subordinate concepts flow from the main concepts;

5. Examine the links and assign directional arrows to the lines for levels of concepts; and

6. Re-arrange the concept map to clearly display the relationships between the concepts.

\subsection{The concept map of Population}

The comparison of the population concept map for the United States and China revealed several commonalities and several differences. On the one hand, the two standards used similar terminology. For example, distribution, area-space, ethnicity, and characteristics of the population were common terminology. On the other hand, there are a greater number of concepts in the U.S. document. There are also other differences between the content standards for the countries. Many concepts in the U.S. standards were not included in China, such as migration of population and the consequences of migration. Some concepts were not obvious in the standards for China, such as crude birth rate, crude death rate, mortality, fertility, doubling time and natural time (Fig. 3 and 4).

The inclusion of population concepts and the agreement between China and United States is demonstrated in Table 6. The concepts in Table 6 represent the way in which each set of standards recognises the concepts that are in agreement. The similar knowledge was represented in different ways. For example, "The natural increase and doubling time of population" in the standard of United States is similar to "Trend in population change" in the standard of China. 


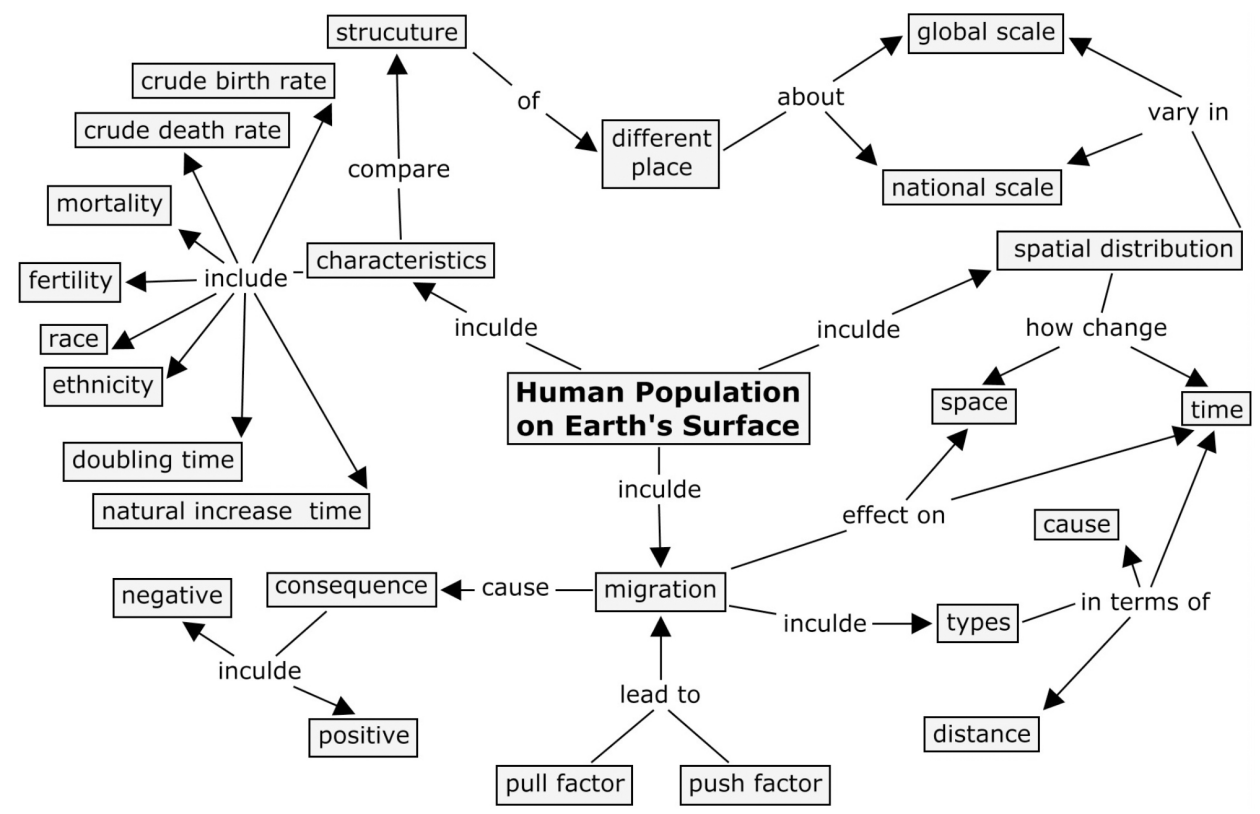

Fig. 3: Human population on Earth's surface concept map for the United States. The concept map displays the concept and linkage among concepts. Only the major concepts were included.

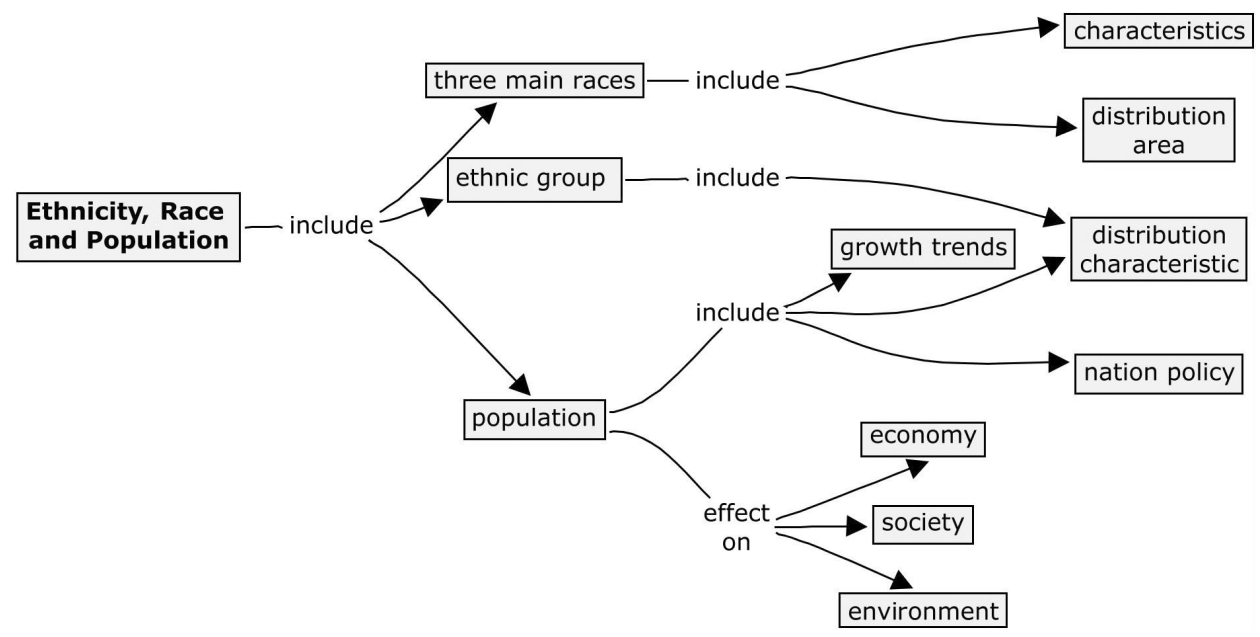

Fig. 4: Ethnicity, race, and population for China. The concept map displays the concepts and linkage among concepts. The major concepts from world geography and the geography of China are included. 


\begin{tabular}{|l|l|}
\hline \multicolumn{1}{|c|}{ United States } & \multicolumn{1}{c|}{ China } \\
\hline $\begin{array}{l}\text { The characteristics, distribution, and migration } \\
\text { of human populations on Earth's surface }\end{array}$ & $\begin{array}{l}\text { Race and population in world geography; } \\
\text { Ethnicity and population in geography of China }\end{array}$ \\
\hline $\begin{array}{l}\text { The natural increase and doubling time of } \\
\text { population }\end{array}$ & Trends in population change \\
\hline $\begin{array}{l}\text { The consequence of migration for people as } \\
\text { well as places of origin and destination places }\end{array}$ & $\begin{array}{l}\text { Effects on economy, society and environment } \\
\text { of overpopulation }\end{array}$ \\
\hline Race and ethnicity & $\begin{array}{l}\text { Three main races, their distribution; Ethnic } \\
\text { groups distribution in China }\end{array}$ \\
\hline $\begin{array}{l}\text { Character of population, demographic concept; } \\
\text { Spatial distribution of population }\end{array}$ & $\begin{array}{l}\text { Distribution characteristics for China and } \\
\text { world populations }\end{array}$ \\
\hline
\end{tabular}

Tab. 6: Similarities between geography standards for the United States and China when population is rendered as a concept map

\subsection{The concept map of Physical system}

In the U.S. content standards, there are two that comprise physical systems. The concepts are based on physical process, ecosystems and biomes (Fig. 5).

In China, the physical components of the concept map include Earth, land and oceans, and Climate as main topics. The concept map includes numerous subordinate concepts that are linked to the major concepts (Fig. 6).

The concept maps for physical systems and Earth, land and oceans, and Climate are similar. This is the result of the interrelationships between the Earth's physical processes. Compared with the U.S. standards, the content-related ecosystems, biomes were not included in the geography standards of China. The concept and content of Physical systems is also not mentioned in the geography standards of China. Moreover, the depth of the content included in each of the concept maps varies with regard to specificity. For example, in China the radius of the Earth is listed as a concept within the content standards whereas in the U.S., the Earth's radius is not a concept addressed in the content standards.

\section{Conclusion}

This publication aimed to draw out notable characteristics in content standard of school geography from two countries. There are many similarities between the middle school content standards in geography for China and the United States. First, the standards for both countries present a rigorous study of the discipline and its wide range of topics. Spatial attributes of the discipline are included in each instance. Second, the content standards represent an approximation of a learning progression adapted to the middle school 


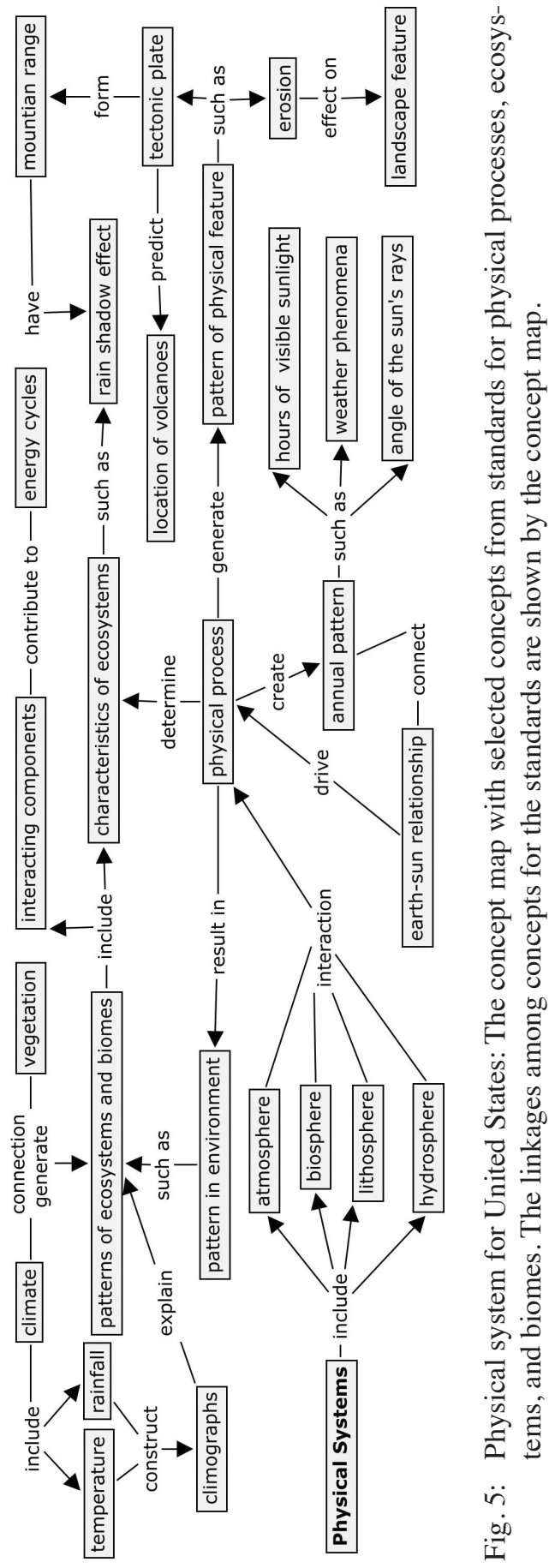




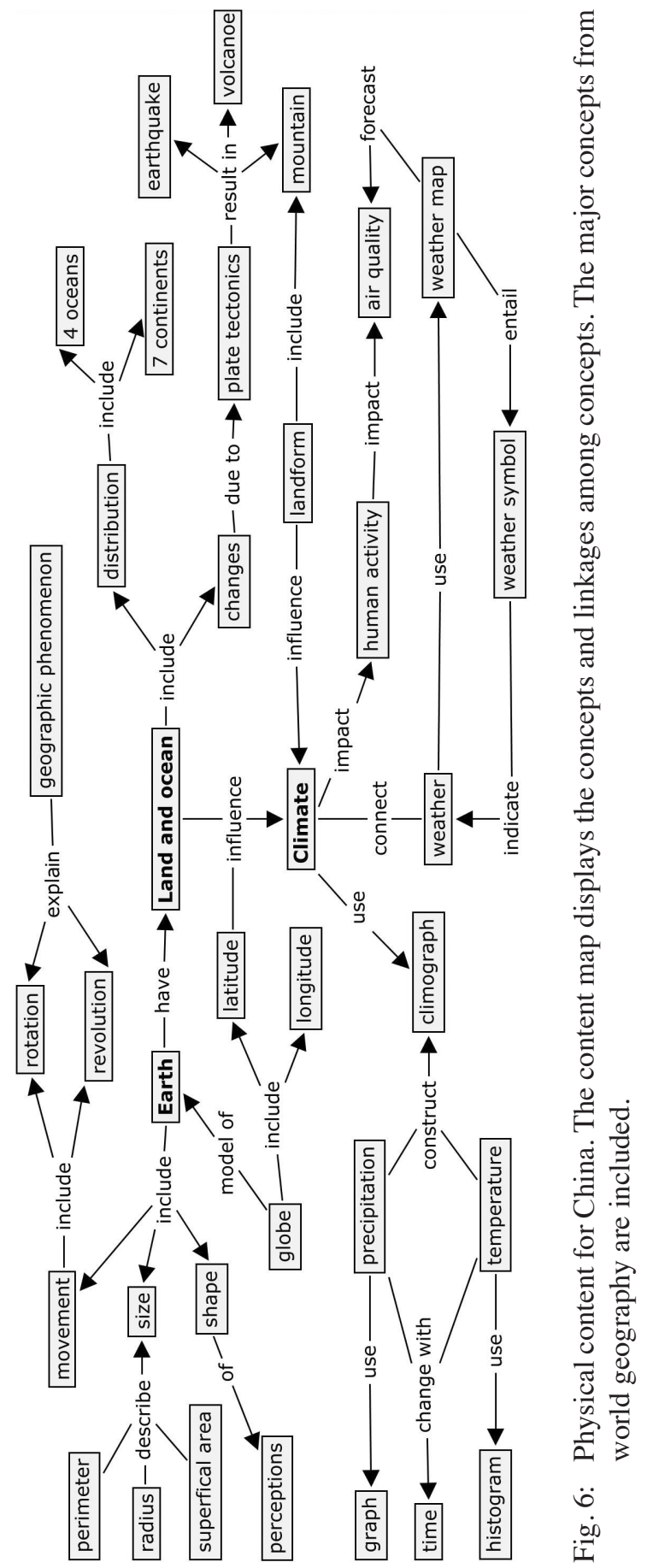


clientele, the age group addressed in this paper. Third, the standards for each country include examples of classroom practices and strategies that may be implemented to prepare students in the content and skills of the discipline.

However, there are also significant differences between the content standards for China and the United States. First, the standards for China are fewer in number due to not including knowledge statement. The implication is that students will address fewer topics, but they will study them in greater detail. Second, teachers in China have fewer choices in the range of content they are expected to teach. In China, a major goal for the student and teacher is successful completion of the college entrance examination when students reach high school. That process begins in the middle school. Absence of a high-school entrance examination in geography education at the middle school is viewed as a hindrance to continuous performance. Third, the content standards of China represent a national curriculum. In the United States the content standards for geography rely on voluntary usage by teachers, schools, and State Departments of Education.

The governmental policies for education in both countries affect the role of the geography standards and greatly explain the differences in their implementation. Considering the policy differences, it is surprising that there are not even greater differences between the documents. The similarities result largely from the nature of geography, whether through a Chinese or American viewpoint. The comparison does reveal the importance of geography in the education of young people, to borrow BuTT's (2011a) assertion, can provide students with "dynamic, inspirational, relevant and powerful ways of visualizing the world" (p. 1). This comparison of geography standards may provide more opportunities for international teacher exchanges in order to disseminate the powerful geography knowledge, skill and values that are necessary in geography of middle school.

This paper just compares the content standards in China and the U.S. As a next step we will talk about questions in implementation, the teaching process and assessment in secondary school. Such as U.S. geography materials teach concepts and theories, conceptual and critical thinking; for Chinese teachers a much higher priority is teaching fact and exam skills in order to prepare the text and get high score. This leads to different qualities of geographic instruction.

\section{References}

AldRICH R. (2000), Educational standards in historical perspective. In: Proceedings of the British Academy, 102, pp. 39-67.

American Federation of Teachers (ed.) (2009), The instructional demands of standards-based reform. - http://www.aft.org/sites/default/files/instructionaldemands0609.pdf

Australian National University - Academic Skills and Learning Centre (ANU-ASLC) (2009), Writing a document analysis. - https://academicskills.anu.edu.au/resources/handouts/writing-document-analysis (accessed November 7; 2014).

Bowen G.A. (2009), Document Analysis as a Qualitative Research Method. In: Qualitative Research Journal, 9, 2, pp. 27-40. 
Butt G. (2011), Introduction. In: Butt G. (ed.), Geography, education and the future, pp. 1-11. London, Continuum.

Butt G., LAMBERT D. (2014), International perspectives on the future of geography education: an analysis of national curricula and standards. In: International Research in Geographical and Environmental Education, 23, 1, pp. 1-12.

Chen Ch., Lin P. (2012), Compulsory Education Geography standard interpretation. In: High education press, pp. 2-6.

Cur Y., Zhu Y. (2014), Curriculum reforms in China: history and the present day. In: Revue internationale d'éducation de Sèvres, Colloque: L'éducation en Asie en 2014: Quels enjeux mondiaux? - http://ries.revues.org/3846 (accessed October 13, 2014).

GABBARD D.A. (2003), A nation at risk reloaded: Part I and II. In: Journal for Critical Educational Policy Studies, 1. - http://www.jceps.com/index.php?pageID=article\&articleID $=15$ (accessed December 7, 2010).

Gallagher-Heffron S., Downs R. (eds.) (2012), Geography for Life, $2^{\text {nd }}$ edition. Washington, D.C., National Council for Geographic Education.

Holly C.D.; Dansereau D.F. (1984), Networking: The technique and the empirical evidence. In: Holly C.D. Dansereau D.F. (eds.), Spatial learning strategy: Techniques, applications and related issues, pp. 81-108. New York, Academic Press.

Hopmann S.T. (2007), Epilogue: No child, no school, no state left behind: Comparative research in the age of accountability. In: Hopmann S.T., Brinek G., Retzl M. (eds.), PISA zufolge PISA. Hält PISA was es verspricht? pp. 363-415. Wien, LIT.

KLiebard H.M. (1995), The Tyler Rationale revisited. In: Journal of Curriculum Studies, 27, 1, pp. $81-88$.

LAMBERT D. (2011), Reframing school geography: a capability approach. In: ButT G. (ed.), Geography, education and the future, pp. 127-140. London, Continuum.

Li X., HuAng Ch. (1997), Geography for Life, $1^{\text {st }}$ Chinese Edition. Taipae, Ministry of Education.

Merriam S.B. (1988), Case study research in education: A qualitative approach. San Francisco, Jossey-Bass.

Ministry of Education of the People's Republic of China (ed.) (2011), Geography Curriculum Standards for Compulsory Education. Beijing, Beijing Normal University Press.

NovaK J.D. (1972), Audio-tutorial techniques for individualized science instruction in the elementary school. In: TrIEZENBERG H. (ed.), Individualized science: Like it is, pp. 14-30. Washington, D.C., National Science Teachers Association.

NovaK J.D. (1990), Concept mapping: A useful tool for science education. In: Journal of Research in Science Teaching, 27, pp. 937-949.

NovaK J.D., Gowin D.B. (1996), Learning How To Learn. New York, Cambridge University Press.

Ravitch, D. (1995), National standards in American education: A citizen's guide. Washington, D.C., Brookings.

Rhoten D., Carnoy M., Chabra'n M., Elmore R. (2003), The conditions and characteristics of assessment and accountability. In: Carnoy M., Elmore R., Santee Siskin L. (eds.), The new accountability: High schools and high-stakes testing, pp. 13-54. New York, Routledge Falmer.

Rowell R. (1978), Concept mapping: Evaluation of children's science concepts following audio-tutorial instruction. Unpublished doctoral dissertation, Cornell University.

SHI L., CuI Y. (1999), Instructional theory: the principle, strategy and research of classroom teaching. Shanghai, East China Normal University Press.

TYLER R.W. (1950), Basic principles of curriculum and instruction, syllabus for Education 360. Chicago, University of Chicago Press. 
U.S. Department of Education (DOE) (ed.) (2002), No Child Left Behind: A desktop reference. http://www2.ed.gov/admins/lead/account/nclbreference/index.html (accessed November 22, 2014).

U.S. National Commission on Excellence in Education (NCEE) (ed.) (1983), A nation at risk: The imperative for educational reform. In: Elementary School Journal, 84, 2, pp. 113-130.

WaLdow F. (2015), From Taylor to Tyler to No Child Left Behind: Legitimating educational standards. In: Prospects, 45, pp. $49-62$.

Yuan X. (2012), Geography for Grade-7 (First Semester). Beijing, People's Education Press.

ZHong Q. (2001), Interpretation of the Outline of the Reform of Basic Education Curriculum (Trial). Shanghai, East China Normal University Press. 